Kerri A. Odess-Harnish. Making Sense of Leased Popular Literature Collections. A Master's Paper for the M.S. in L.S. degree. April, 2002. 44 pages. Advisor: Barbara B. Moran.

There is a well-publicized debate in the library field on whether or not it should be an academic library's responsibility to collect and preserve popular culture materials. Budget constraints, space issues, and the "quality" of these materials, are all widely documented concerns as to why popular culture materials - especially popular literature titles - are still not making their way into an academic library's permanent collection. This study describes a survey of 22 academic libraries throughout the country that use a leased popular literature collection in addition to or instead of purchasing popular literature titles for their permanent collection. The study was designed to answer the following research questions and others: Why do academic libraries choose to use a leasing plan to provide a popular literature collection for their users? What are the values/benefits these collections provide for the library and its users?

Headings:

College and university libraries--Acquisitions

College and university libraries--Collection development

Fiction--Acquisitions

Special collections--Special subjects--Popular culture

Surveys--College and university libraries 


\title{
MAKING SENSE OF LEASED POPULAR LITERATURE COLLECTIONS
}

\author{
by \\ Kerri A. Odess-Harnish
}

\begin{abstract}
A Master's paper submitted to the faculty of the School of Information and Library Science of the University of North Carolina at Chapel Hill

in partial fulfillment of the requirements for the degree of Master of Science in Library Science.
\end{abstract}

Chapel Hill, North Carolina

April, 2002

Approved by:

Advisor 


\section{TABLE OF CONTENTS}

Introduction

$\begin{array}{lll}\text { Literature Review } & 7\end{array}$

$\begin{array}{ll}\text { Methodology } & 12\end{array}$

Operational Definitions _ 12

Finding the Institutions/Making Contact __ 13

$\begin{array}{ll}\text { Survey Construction and Delivery } & 14\end{array}$

$\begin{array}{ll}\text { Data Analysis } & 14\end{array}$

Results

$\begin{array}{lll}\text { Conclusion } & 24\end{array}$

$\begin{array}{ll}\text { Works Cited } & 27\end{array}$

Appendix A: Carnegie Classification of Surveyed Institutions __ 29

Appendix B: Text/Sequence of Emails __ 30

Appendix C: Survey Questions __ 31

Appendix D: Tables of Survey Results __ 36 


\section{TABLES}

Table 1: Question 5 16

$\begin{array}{ll}\text { Table 2: Question 7 } & 17\end{array}$

Table 3: Question $8+18$

Table 4: Question $11 \_19$

Table 5: Question $13 \longrightarrow 19$

Table 6: Question 14

Table 7: Question 19__ 21

Table 8: Question 21 22

Table 9: Question 22 _ 23 


\section{INTRODUCTION}

There is a well-publicized debate in the library field on whether or not it should be an academic library's responsibility to collect and preserve popular culture materials. This debate has become increasingly significant as popular culture studies courses have become a common and respectable part of many universities curricula. At the same time, however, budget constraints, space issues, and the idea that these materials are not of a high enough caliber to belong in a research library, are all widely documented concerns as to why popular culture materials - especially popular literature titles — are still not making their way into an academic library's permanent collection.

An academic library builds its collection in order to support the academic pursuits of its current and future users. It is often a daunting task to consider collecting popular literature if it had not been collected before. Adding to the difficulty is that the subject "popular literature" is ambiguous and immense. The use of a leased collection can temporarily resolve this issue by placing a collection of several hundred current massmarket and best-selling titles almost immediately on a library's shelves. This then provides a nucleus of mass-market titles that could be useful for research, as well as a respectable reading collection for those seeking recreational reading materials.

For over 50 years, the McNaughton Book Service of the Brodart Co. has provided libraries of various sizes with leasing plans for maintaining a popular literature collection. The McNaughton Book Service (named after Nelson McNaughton) started out as a commercial lending library business that supplied books to storekeepers who would then 
lend them out for a few cents a day (“Origin"). Near bankruptcy in the late 1940's, McNaughton contacted Arthur Brody of Brodart to ask for help. At that time, McNaughton had begun leasing books to public libraries. While successful in the library side of the lending business, the storekeepers were "robbing him blind" ("Origin"). Arthur Brody, who had seen the success of the leased collections in public libraries agreed to go into business with him if McNaughton would agree to get rid of the other side of the business. The rest is history.

Today, the McNaughton Book Service offers libraries temporary ownership and lending privileges of new and popular titles, and for some, the only place where a user might find contemporary popular fiction in a library's collection. The McNaughton Plan also provides the option for libraries to purchase titles at the end of the leasing period. Based on circulation or other criteria, a library may decide that a certain title should be added to its permanent collection. While seemingly a good solution, this does not however resolve the issue of permanence for all of the titles, thus not ensuring future scholars will have access to these reflections of popular society.

Why then do libraries choose to use a leasing plan to provide a popular literature collection for their users? What services does a leased popular literature collection provide for users in an academic library that are not otherwise provided for by a library's permanent collection? Do these identified services then support or oppose the reasons for the items in the collection being only temporary? What are the values/benefits these collections provide for the library? Is the leased collection considered to be an important service by library staff members and therefore given the same amount of supervision and priority as other collections (ie., are professional staff choosing the titles? Where is the 
collection located in the library? Is the collection advertised?)? This research project attempted to answer these questions by surveying a sample of academic libraries using the McNaughton Book Service for providing popular literature titles in their library. 


\section{LITERATURE REVIEW}

Popular literature is a small portion of what gets categorized under the larger umbrella of "popular culture materials." It is necessary when discussing whether or not popular literature should have a place in an academic setting, to ask the question of what is popular culture and why, historically, are materials that fall under this umbrella seen as unfit for academic/research libraries? In his book An Introductory Guide to Cultural Theory and Popular Culture, John Storey attempts to define popular culture and provides evidence of the fuzzy boundaries of popular culture. He comes up with six definitionsall of which tend to describe popular culture (and therefore, the materials defined as such) as "substandard" (Storey 6-18). That popular culture is in a class below "high culture" commonly means the materials categorized under this category are believed to be less respectable.

Wayne A. Wiegand's essay “The Academic Library’s Responsibility to the Resource Needs of the Popular Culture Community" offers insight into the troubled relationship between academic libraries and popular culture materials and the “indifferent" stance many academic librarians take when collecting popular materials. He suggests that "academic librarians gravitate towards a conservatism" (Wiegand 191) in regard to popular culture materials due to the conservative nature of their education in library school, which commonly only offers training of popular or any alternative materials in specialized, non-required courses. This conservatism, Wiegand believes, is then reinforced when library science students enter the professional field: 
When library science students graduate from professional training programs they usually assume positions in libraries where lines of organizational structure parallel the course divisions in library school curricula. The neophyte librarian finds nonprint media pigeonholed into functionally specialized departments within the library at best, or at worst, separated from the library altogether (as on most university campuses). Thus, preconceptions brought to a chosen field which were steadily nurtured by library science curricula and faculty are ultimately confirmed by library practice. (191)

Furthermore, when observing the literature of the field, Wiegand notes that the majority of writing involves rationalizing already existing library operations instead of breaking the mold and reflecting on the larger service goals. He writes, "Little in library literature reflects a holistic outlook, or seeks to examine the validity of basic assumptions tenaciously clung to for decades" (Wiegand 191).

In a similar essay, Barbara B. Moran states that the "traditional view of collection development in academic libraries will require librarians to undergo an attitudinal change," and while many librarians have already done undergone this change, some are still "bound by a narrow definition of culture" (11). Like Wiegand, Moran believes that many librarians have a love for reading which includes popular literature, but that library science education and the profession does not foster a serious respect for these materials. As it is now clear that academic interest in popular culture is here to stay, Moran believes that librarians need to just deal with these issues and "get on with the business of collecting popular culture..." (10).

The call for building popular literature collections is clear in both the interest of the scholar and the recreational reader. In his article "Trash or Treasure? Pop Fiction in Academic and Research Libraries," Robert G. Sewell reasons that academic libraries need to place more effort on the bibliographic control and preservation of popular 
materials while coordinating collection building on a national and regional level (459460). These steps combined with the cooperative efforts of librarians and popular culture scholars would ensure that the wide array of materials that fall under the umbrella of popular culture materials are collected and accessible for current and future scholars.

Unfortunately, it is evident that the majority of academic libraries are still not responding to the pleas of collecting popular literature in their permanent collection, nor subscribing to any of the ideas for how to share such a large responsibility. In a recent article titled, "Best Sellers in Academic Libraries," Gregory A. Crawford and Matthew Harris researched the holdings of 20 academic libraries on whether or not they carried 220 best-seller titles from 1940-1990. They found that there was a trend to own older best-sellers rather than newer ones (Crawford and Harris 221). This study's findings leads to the question of whether or not libraries are having to retrospectively collect these items instead of collecting them at the time of publication.

There has been very little documented on academic libraries using a leasing service in addition to or instead of permanently collecting popular literature. What little has been written on the subject focuses mainly on the positive outcomes of using a leasing service. In an early article written by Ruth Carol Cushman, the author states, "I submit that the lease plans are a viable alternative to purchasing books for recreational reading and for multiple copies of high-demand books in academic libraries" (15). This conclusion is based on the results of a 1976 survey of fourteen academic libraries that subscribed to a leasing service. Cushman reports that there were common frustrations with late arrivals of popular titles by the leasing vendors, but that the advantages of having the books arrive already processed and ready for the shelf, being able to purchase 
the books at the end of the leasing plan for a discount, the enthusiastic response by their users, and the "fun" of choosing the titles, far outweighed this complaint and others by the surveyed libraries (17).

In a more recent 1998 article "Options for Fiction Provision in Academic Libraries," Janelle M. Zauha also highlights the time, space, and money saving benefits of having a leased collection in an academic library. However, in her follow-up of Cushman's survey of 14 libraries 21 years later, Zauha reports only 7 of the libraries were still using a leasing plan (51). Budget problems were the main reason cited for halting the collections, while changes in administration, and moving toward more economical alternatives to provide the same service were also given (Zauha 52). This seems to show that while the benefits of leased collections are great for a library that places importance on the recreational reading or scholarly pursuit of popular literature by its users, the collections are commonly challenged when budget cuts occur. If libraries wish to continue acquiring leased materials, these collections have to be treated with the same respect and worthiness as other collections in the library.

On a different note, John O. Christensen wrote in his article "Management of Popular Reading Collections," that after studying circulation statistics of the leased reading collection at Brigham Young University, the library found that is was not costeffective to continue using the leasing plan (78). In fact, the library dropped the plan and still continued to support the reading collection through purchasing paperbacks locally.

These articles show the variety of issues surrounding the collection of popular literature in academic libraries, and the experiences a few academic libraries have had in using a leased popular literature collection. However, the lack of research makes it 
difficult to make any generalizations about why libraries have decided to use these plans. This study attempted to shed some light on the many unanswered questions by focusing on what services the library sees these collections providing for their users that are not provided by their permanent collection. 


\section{METHODOLOGY}

This study is designed to answer the following research questions. 1. Why do academic libraries choose to use a leasing plan to provide a popular literature collection for their users? 2. What services does a leased popular literature collection provide for users in an academic library that are not otherwise provided for by a library's permanent collection? 3. What are the values/benefits these collections provide for the library? 4 . Is the leased collection considered to be an important service by library staff members and therefore given the same amount of supervision and priority as other collections (ie., are professional staff choosing the titles? Where is the collection located in the library? Is the collection advertised?)?

\section{Operational Definitions:}

1. In this study, an academic library is defined as a library in an institution of higher education that is classified as a "Doctorate-granting Institution," a "Master's College and University," a "Baccalaureate College," a "Specialized Institution," or an "Associates College" according to the 2000 edition of The Carnegie Classification of Institutions of Higher Education (see Appendix A).

2. In this study, a popular literature collection is defined as a distinct collection shelved separately from a library's general collection of materials that includes recently published blockbuster/mass-market titles. These collections are also frequently composed of, but not exclusive to, genre fiction (romance, mysteries, westerns, etc.) and biographies.

3. In this study, a leased collection of popular literature is a collection provided by an outside vendor, such as the McNaughton Book Service, to provide temporary ownership of popular literature titles that can be borrowed by that library's users. The titles leased are selected by library staff and returned to the vendor after the contracted time period of temporary ownership has expired. 
Finding the Institutions/Making Contacts:

The names of the colleges and universities that were part of the study were gathered in two ways. First, the researcher contacted the customer service center of the McNaughton Book Service (1-800-233-8467) and inquired about universities that used their services. In this way, the names of twelve schools were identified. Second, the author searched the World Wide Web using the search engine Google (http://www.google.com) using the key search terms: "mcnaughton collection," "mcnaughton collection and library," and "mcnaughton collection and university." An additional 17 colleges and universities were identified using this technique.

After the names of 29 institutions had been gathered, the researcher began contacting the libraries of these institutions to identify the name and email addresses of the library staff member(s) who supervise/manage their leased popular literature collection. By emailing the "Ask a Question" service on a library's website, or using the "Chat Reference" service when available via the library's or reference department's website, the researcher collected names and email addresses of potential participants.

Following this initial contact, the researcher emailed each of the provided names of library staff members to: 1) inquire about whether or not he or she was the correct person to be in discussion with, and 2) to inquire about a willingness to participate in this study. The researcher heard back from 25 staff members. A follow-up email was sent to these 25 library staff members thanking them for their willingness to participate and requesting their mailing address (see Appendix B for the text of all emails sent by the researcher). 


\section{Survey Construction and Delivery:}

The survey used to gather data is a mixture of both open-ended and closed-ended questions (see Appendix $\mathrm{C}$ for the complete list of questions included in the survey). The survey's questions and appearance were constructed based on the design methods outlined in Don A. Dillman's Mail and Telephone Surveys: The Total Design Method.

The survey was pretested by four individuals: a library administrator who is the head of a library which uses the McNaughton Book Service, a reference librarian, a library staff member involved in choosing titles for a leased collection, a library science student, and an individual with no ties to the library field. This pretest was to make certain the survey's readability and appropriateness of topic, as well as for creating a forum for suggestions in regard to the content either already present or missing entirely.

After the pretest, 25 surveys were mailed to the library staff members who were identified as responsible for maintaining the leased popular literature collection in their libraries and who responded to the researcher's emailed requests as being willing to participate in this study.

\section{Data Analysis:}

Twenty-two out of 25 surveys were returned (a response rate of $88 \%$ ). As the surveys were returned, responses to each question were recorded onto data tables for compiling. Questions that required written responses were recorded as they appeared. These responses were then read through carefully to find commonalities. These common findings were then summarized into statements for brevity and clarity. No response was left out even if it was cited only once. The results of the survey are below. 


\section{RESULTS}

Question 1 of the survey asked each library how long they have used the McNaughton Book service to lease a popular literature collection. The answers ranged from 1.5 to 35 years (with a total average of 12.3 years). In question 2, the survey asked whether or not any other company was considered besides McNaughton. Eighteen out of 22 responded "no," 2 responded that their library had considered the Baker and Taylor lending service, and another 2 did not know whether or not any other company had been considered.

Question 3 of the survey asked if the staff member's library leases popular literature titles instead of collecting popular literature for the library's permanent collection. Fourteen out of $22(64 \%)$ responded "yes," while $8(36 \%)$ responded that "no." When asked in question 4 if the library leases popular literature titles in addition to collecting popular literature for the library's permanent collection, the answers were split: 11 out of $22(50 \%)$ answered "yes," and the other $11(50 \%)$ answered "no."

Question 5 of the survey asked if the staff member thought that their library should be doing more to collect popular literature titles (especially those considered to fall under the genres of romance, mystery, western, and science fiction) in the permanent collection (see Table 1 below). One hundred percent (22 out of 22) of those who responded answered "no," that they did not believe that their library should be doing more to collect popular literature titles. There were 9 explanations commonly given in response to the second part of question 5 that asked "Why/Why Not?" Thirteen out of 22 
cited that popular literature titles are not part of the curriculum the library supports; space constraints was cited twice; budget constraints was cited 4 times; and the interest /demand of the popular literature titles is not long-lasting enough was also cited twice. In addition, the following 5 responses were each cited once as reason for why their library should not be doing more to permanently collecting popular literature titles: there is a public library near by; they already purchase enough popular literature titles; the library will purchase if requested to: students don't have time for pleasure reading; and, that the effort required to maintain a permanent popular literature collection would detract from maintaining the permanent collection.

Table 1: Question 5

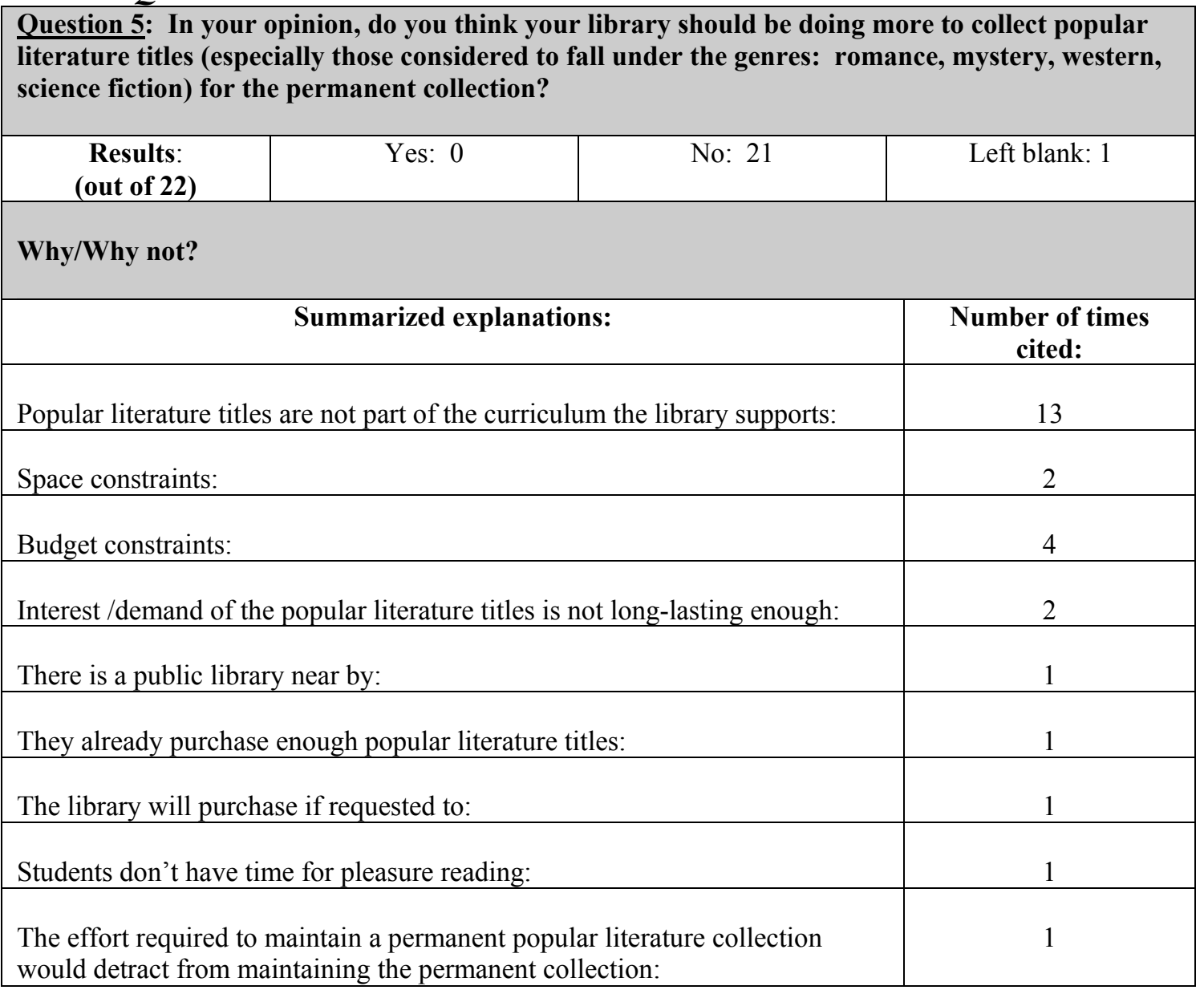


Question 6 of the survey asks if whether or not the university/college that the library supports has popular culture courses that would benefit from having popular literature as part of the permanent collection. Nine out of 22 (41\%) responded "yes," 12 (55\%) responded "no," and 1 responded "maybe."

In question 7, the staff members were asked to circle options from a provided list of seven categories to show what kinds of books were included in their library's leased collection. Table 2 below lists these results in addition to the categories written in by the respondents to show what other kinds of books are included in their library's leased collection.

Table 2: Question 7

\begin{tabular}{|l|c|l|c|}
\hline \multicolumn{3}{|l|}{$\begin{array}{l}\text { Question 7: From the list below, please circle the categories of books included in your library's } \\
\text { leased popular literature collection: }\end{array}$} & $\begin{array}{c}\text { Number of times } \\
\text { selected by } \\
\text { respondents: }\end{array}$ \\
\hline $\begin{array}{c}\text { Categories of } \\
\text { books: }\end{array}$ & $\begin{array}{c}\text { Number of times } \\
\text { selected by } \\
\text { respondents: }\end{array}$ & $\begin{array}{l}\text { Categories of books: } \\
(82 \%)\end{array}$ & $\begin{array}{c}22 \\
(100 \%)\end{array}$ \\
\hline Romance: & 15 & Science-Fiction: & 21 \\
\hline Westerns: & $(68 \%)$ & Nonfiction: & $(95 \%)$ \\
\hline Best-Selling General & 22 & & 21 \\
Fiction: & $(100 \%)$ & & $(95 \%)$ \\
\hline Biographies: & 22 & & \\
\hline & $(100 \%)$ & Self-Help: & \\
\hline Business Nonfiction: & Other categories of books written in by respondents: & \\
\hline How-to books: & 2 & Spirituality: & 1 \\
\hline Cookbooks: & 1 & Travel: & 1 \\
\hline College Life: & 1 & Food: & \\
\hline
\end{tabular}

Question 8 asked how many titles, on average, make up the leased collection in each library. The responses were varied and for ease of reporting, were categorized in 
ranges. These ranges and the number of libraries that answered within each range are outlined in Table 3 below.

Table 3: Question 8

\begin{tabular}{|l|c|l|c|}
\hline \multicolumn{4}{|c|}{ Question 8: How many titles, on average, make up the leased literature collection? } \\
\hline $\begin{array}{c}\text { Range of number of } \\
\text { titles: }\end{array}$ & $\begin{array}{c}\text { Number of times cited } \\
\text { in that range (out of } \\
\text { 22): }\end{array}$ & $\begin{array}{c}\text { Range of number of } \\
\text { titles: }\end{array}$ & $\begin{array}{c}\text { Number of times cited } \\
\text { in that range } \\
\text { (out of 22): }\end{array}$ \\
\hline $0-199:$ & 1 & $600-799:$ & 2 \\
\hline $200-399:$ & 8 & $800-999:$ & 2 \\
\hline $400-599:$ & 8 & $1000+:$ & 1 \\
\hline
\end{tabular}

Question 9 asked if the titles in the leased collection circulate: a) more than what was expected when the collection was added, b) less than what was expected when the collection was added, or c) about what was expected when the collection was added. Fifty-four percent (12 out of 22) chose option “c," 23\% (5 out of 22 ) chose "a," 14\% (3 out of 22) chose option "b," while 9\% (2 out of 22) left the question unanswered.

Question 10 of the survey asked for the professional title of the library staff member who is in charge of choosing the titles for the leased collection. The responses varied greatly (from music librarian to library director to all library staff-including students) and thus, it was not possible to identify the predominant or most common professional title.

Question 11 of the survey asked that each respondent choose all that applied from a list of four options to describe the staff member who is in charge of selecting titles for the leased collection (see Table 4). These options and the number of times each was chosen are: option a) "has personal interest in popular literature" was circled by 18 out of $22(82 \%)$; option b) "when reading for pleasure, this staff member reads genre fiction" was circled by 11 out of 22 (50\%); option c) "has collection development 
training/experience" was circled by 16 out of $22(73 \%)$; and option d) "was chosen at random to be in charge of selecting titles for the collection without having any personal interest in popular literature" was circled by 4 out of $22(18 \%)$.

Table 4: Question 11

\begin{tabular}{|c|c|c|c|c|}
\hline \multicolumn{5}{|c|}{$\begin{array}{l}\text { Question 11: Please select all that apply from the following options to describe the staff member } \\
\text { who is in charge of selecting titles for the leased popular literature collection: } \\
\text { a. Has personal interest in popular literature. } \\
\text { b. When reading for pleasure, this staff member reads genre fiction } \\
\text { (westerns/mysteries/romance/science fiction). } \\
\text { c. Has collection development training/experience. } \\
\text { d. Was chosen at random to be in charge of selecting titles for the collection without having } \\
\text { any personal interest in popular literature. }\end{array}$} \\
\hline Results: & $\begin{array}{l}\text { A: } 18 \\
(82 \%)\end{array}$ & $\begin{array}{l}\text { B: } 11 \\
(50 \%)\end{array}$ & $\begin{array}{l}\mathrm{C}: 16 \\
(73 \%)\end{array}$ & $\begin{array}{c}\mathrm{D}: 4 \\
(18 \%)\end{array}$ \\
\hline
\end{tabular}

Question 12 asked if the person in charge of choosing titles for the leased

collection has an M.L.S. Seventy-three percent (16 out of 22) answered "yes," 18\% (4 out of 22) answered "no," and 9\% (2 out of 22) answered both "yes" and "no" explaining that more than one staff member is in charge of choosing titles and some have an M.L.S., while others don't.

Question 13 of the survey asked on average, what percent of the titles from the leased collection is purchased by the library each year after the leasing period is over. Again, the answers varied widely, so ranges were created for ease of reporting. These ranges and the number of respondents who answered within each range are included in Table 5 below.

\section{Table 5: Question 13}

\begin{tabular}{|c|c|c|c|}
\hline Range of percent: & $\begin{array}{l}\text { Number reported in } \\
\text { that range out of } 22 \text { : }\end{array}$ & Range of percent: & $\begin{array}{l}\text { Number reported in } \\
\text { that range out of } 22 \text { : }\end{array}$ \\
\hline $0 \%$ : & 8 & $21-30 \%:$ & 4 \\
\hline $1-10 \%:$ & 6 & $31-40 \%:$ & 2 \\
\hline $11-20 \%$ : & 1 & $41 \%+:$ & 1 \\
\hline
\end{tabular}


Question 14 asked the respondents for the criteria used to select titles from the leased collection for purchasing and to add to the permanent collection (example: circulation statistics, name recognition, etc). Again, the answers were varied and numerous. The researcher found that the cited responses could be summarized into 10 categories of criteria. These criteria and the number of respondents who cited each are listed below in Table 6 .

Table 6: Question 14

\begin{tabular}{|l|c|}
\hline \multicolumn{2}{|c|}{ Question 14: What are the criteria used to select titles from the leased collection for purchasing } \\
and adding to the permanent collection? (Example: circulation statistics; name recognition; etc.) \\
\hline \multicolumn{1}{|c|}{ Criteria reported: } & Number of times cited in survey: \\
\hline Name recognition/well-known author: & 8 \\
\hline Circulation statistics: & 8 \\
\hline If it supports curriculum: & 4 \\
\hline If requested for purchase by faculty/staff member: & 4 \\
\hline If a title is well-reviewed: & \\
\hline We don't purchase at all: & 4 \\
\hline If a title has enduring value: & 1 \\
\hline Titles are chosen at random (has interesting title, etc.): & 1 \\
\hline If it's in good physical condition: & 1 \\
\hline If a title is of regional interest: & \\
\hline
\end{tabular}

Question 15 of the survey asked where the leased collection is physically located in each of the libraries. The answers varied, but could be categorized as follows (note: a library could have cited more than one of these location reference points if their collection was located for example between the reference desk and periodicals): "On the main floor of the library" was cited the most at 8 times; "In a reading room" was cited 5 times; "Near the periodicals" was cited 4 times; "Near the main entrance to the library" 
was also cited 4 times; "Near the reference desk" was cited 3 times; and "Near the circulation desk" was cited 2 times. A category of "Other" was cited 5 times which included responses that did not fall into any previous category. The locations in this category ranged from basement of the library to near the student lounge on the $2^{\text {nd }}$ floor of the library.

Question 16 of the survey asked if there is proper signage leading users to the leased collection without their having to ask a staff member for direction. Sixty-four percent (14 out of 22) answered "yes," 32\% (7 out of 22) answered "no," and 1 respondent left the question unanswered.

Question 17 asked if the leased collection is mentioned on the library's website. Sixty-four percent (14 out of 22) answered "yes," 36\% (8 out of 22) answered "no."

Question 18 asked if there is a reading room near the leased collection that provides for comfortable and relaxed reading. One hundred percent of the respondents (22 out of 22) answered "yes."

Question 19 of the survey asked the respondents to choose from options provided to show who uses the leased collection the most. The options to choose from were: a) Staff/Faculty, b) Undergraduate Students, c) Graduate Students, and d) Community Members. See Table 7 below for the responses given.

Table 7: Question 19

\begin{tabular}{|c|c|}
\hline Options: & Number of times selected: \\
\hline a. Staff/Faculty: & 13 \\
\hline b. Undergraduate Students: & 3 \\
\hline c. Graduate Students: & 0 \\
\hline d. Community Members: & 0 \\
\hline Other (combinations chosen by respondent): & $a b=4, a c=1, a b c d=1$ \\
\hline
\end{tabular}


Question 20 asked for the respondent to choose from three options provided to report what they feel is the main reason the collection is used for. The options provided were: option a) Pleasure reading; option b) Research for a popular culture studies course; and option c) A balanced mix of both pleasure and reading and research. One hundred percent (22 out of 22 ) reported that the collection is mainly used for pleasure reading.

Question 21 of the survey allowed for the respondent to report what service they believe the leased popular literature collection provides for their users that their library's general collection does not. The variety of answers given were summarized by the researcher into 5 categories and are listed below in Table 8 .

Table 8: Question 21

\begin{tabular}{|l|c|}
\hline \multicolumn{1}{|l|}{$\begin{array}{l}\text { Question 21: In your opinion, what service does the leased popular literature collection provide } \\
\text { for your users that your library's general collection does not? }\end{array}$} \\
\hline \multicolumn{1}{|c|}{ Services reported: } & Number of times cited: \\
\hline Access to current/popular titles: & 15 \\
\hline Recreational reading: & 4 \\
\hline $\begin{array}{l}\text { Expands the range/variety of reading materials available } \\
\text { on campus: }\end{array}$ & 2 \\
\hline $\begin{array}{l}\text { Saves time and money of users (don't have to purchase } \\
\text { new books or go to public library): }\end{array}$ & 2 \\
\hline \begin{tabular}{l} 
Provides multiple copies of popular titles: \\
\hline
\end{tabular} & 2 \\
\hline
\end{tabular}

When asked in question 22 to report what values/benefits having a leased popular literature collection provides for the library, 10 categories provided the basis for the varied responses given. See Table 9 below for these reported values/benefits that were identified by the respondents. 
Table 9: Question 22

\begin{tabular}{|l|c|}
\hline \multicolumn{1}{|l|}{ Question 22: In your opinion as a library staff member, what are the values/benefits of having a leased } \\
popular literature collection in your library? & Number of times cited: \\
\hline \multicolumn{1}{|c|}{ Values/benefits reported: } & 70 \\
\hline Access/convenience to popular literature titles: & 7 \\
\hline Pleasure reading material: & 5 \\
\hline Good public relations tool: & \\
\hline Cost-effective for library (access without have to purchase): & 4 \\
\hline Adds variety to library collection: & 2 \\
\hline $\begin{array}{l}\text { Library staff members are able to review titles before } \\
\text { purchasing: }\end{array}$ & 2 \\
\hline Promotes discussion and life-long reading: & 2 \\
\hline Multiple copies/quick turnover of recent titles: & 2 \\
\hline Saves space: & \\
\hline Alleviates stress on the local public library: & \\
\hline
\end{tabular}

Question 23, the final question of the survey, asked the respondents to write down any additional comments that they thought were missed in the survey. Only 8 out of 22 had comments to add. These ranged from explaining further how the leased collection was managed in a particular library to reiterating the benefits of having such a collection. Others included comments such as how the collection when first started used to be referred to as the "trash collection" by the professional staff, while another stated that having the collection in his/her library provides a good place to promote multiculturalism by having popular minority authors and biographies in the collection. Another reported that if the collection was removed, there would probably be a protest. 


\section{CONCLUSION}

Although this study is small in scale, the results gathered do help to shed some light on why academic libraries choose to use leased popular literature collections. It can be concluded from the survey findings that libraries believe the main service these collections provide for their users is material for recreational reading — a service that their permanent collection does not otherwise adequately provide. While having access to recreational reading materials is important on a college/university campus, it is disconcerting to find that $100 \%$ of the responding library staff members believe that their library should not be doing anything more to permanently collect popular literature. The top four reasons given were that the titles are not applicable to the curriculum the library is supporting, budget and space constraints, and that the interest and value of these titles are not usually long-lasting enough to warrant purchasing. It is not surprising then that $64 \%$ of the libraries claim that they lease popular literature titles instead of purchasing popular literature for their permanent collection.

For those libraries that do purchase titles from their leased collection to add to their permanent collection, the top three reported criteria used for selection were name recognition/well-known author, if the title supports the college curriculum, and circulation statistics. While this shows sound collection development guidelines (and the results of the survey do indicate that the library staff member(s) who manage the leased collections are mostly professional staff with collection development training/experience and who have a personal interest in popular literature) it also suggests that the only 
popular literature titles being collected are the exceptional bestsellers and/or titles that are somehow identified as supportive of an existing class or curriculum. This however, seems to contradict the results of the survey as only 3 survey participants claimed that their library purchases more than $30 \%$ of the leased titles. According to the McNaughton Book Service website only "high demand" titles are available to lease:

Each month McNaughton reviews hundreds of soon-to-be published titles to ensure that all selections will be high demand titles. The McNaughton review sources include: The New York Times Bestsellers, Library Journal, Kirkus Reviews, Booklist, and Publishers Weekly. ("Concept of Leasing")

It could be assumed then that the majority of the titles that come through the doors of the libraries surveyed via the McNaughton Book Service are still not being purchased, no matter how popular or in-demand the titles are.

Although it seems popular literature has a long way to go before what falls under this label is purchased and preserved alongside titles considered to be of a high enough caliber to be collected in academia, the McNaughton collections are generally wellmaintained and well-used according to the survey participants. Fifty-four percent of the respondents reported that the titles circulate at least as much as was expected when their library began using the plan, with another $23 \%$ reporting that the titles circulate more than was expected.

A future study on this same topic could look further into the physical location of these collections. Comparing the location with circulation statistics and the amount of titles purchased at the end of the leasing period could reveal how much professional attention is given to the collection as well as how valued it is by library staff. It would also be interesting to find if there is a correlation among the libraries who use these leased collections today with those campuses that have historically valued reading rooms 
and leisure collections like those that were so popular on college campuses in the 1920's and 1930's. And finally, it would be interesting to compare the results of this research project with a similar project of a larger scale. The researcher was surprised with the amount of enthusiasm she was met with when contacting library staff members to solicit their help with this project. As stated earlier, there is a general lack of literature about the use of leased popular literature collections in academic libraries. This then translates into a lack of understanding of how and why libraries decide to use them.

Popular literature materials are not going away, nor are courses on college campuses that focus on popular culture and society. This research project indicates that these materials still need to be given greater consideration in academic library collections. Popular literature is still being set aside primarily due to the label that it wears. 


\section{WORKS CITED}

Christensen, John O. "Management of Popular Reading Collections." Collection Management. 6.3-4 (1984): 75-82.

"The Concept of Leasing.” McNaughton Book Service. Brodart Co. 31 March 2002. $<$ http://www.brodart.com/books/mcn/adltbook.htm>.

Crawford, Gregory A. and Matthew Harris. "Best Sellers in Academic Libraries." College \& Research Libraries. 62.3 (May 2001): 216-225.

Cushman, Ruth Carol. "Lease Plans-A New Lease on Life For Libraries?” The Journal of Academic Librarianship. 2.1 (1976): 15-19.

Dillman, Don A. Mail and Telephone Surveys: The Total Design Method. New York: John Wiley \& Sons, 1978.

McCormick, Alexander C. ed. The Carnegie Classification of Institutions of Higher Education, 2000 Edition. The Carnegie Foundation for the Advancement of Teaching, 2000. 25 Feb. 2002.

$<$ http://www.carnegiefoundation.org/Classification/index.htm $>$.

Moran, Barbara. "Going Against the Grain: A Rationale for the Collection of Popular Materials in Academic Libraries.” Popular Culture and Acquisitions. 8 (1992): $3-12$.

"The Origin of the McNaughton Plan As Told by Art Brody." Library Journal. 114.8 (1989): 85 . 
Sewell, Robert G. "Trash or Treasure? Pop Fiction in Academic and Research Libraries." College \& Research Libraries. 45 (November 1984): 450-461. Storey, John. An Introductory Guide to Cultural Theory and Popular Culture. Athens: University of Georgia Press, 1993.

Wiegand, Wayne A. “The Academic Library's Responsibility to the Resource Needs of the Popular Culture Community." Twentieth-Century Popular Culture in Museums and Libraries. Ed. Fred E. H. Schroeder. Bowling Green, Ohio: Bowling Green University Popular Press, 1981. 189-198.

Zauha, Janelle M. "Options for Fiction Provision in Academic Libraries: Book Lease Plans.” The Acquisitions Librarian. 19 (1998): 45-54. 


\section{APPENDIX A}

\section{Carnegie Classification of Surveyed Institutions}

- Classification and definitions from: The Carnegie Classification of Institutions of Higher Education, 2000 Edition.

\begin{tabular}{|c|c|}
\hline Description of each classification: & $\begin{array}{l}\text { Total number } \\
\text { surveyed out of } \\
\text { 22: }\end{array}$ \\
\hline $\begin{array}{l}\text { Specialized Institutions - Schools of business and management: } \\
\text { - "These institutions award most of their bachelor's or graduate } \\
\text { degrees in business or business related fields." }\end{array}$ & 1 \\
\hline $\begin{array}{l}\text { Master's Colleges and Universities I: } \\
\text { - "These institutions typically offer a wide range of baccalaureate } \\
\text { programs, and they are committed to graduate education through the } \\
\text { master's degree. During the period studied, they awarded } 40 \text { or more } \\
\text { master's degrees per year across three or more disciplines." }\end{array}$ & 9 \\
\hline $\begin{array}{l}\text { Doctoral/Research Universities-Intensive: } \\
\text { - "These institutions typically offer a wide range of baccalaureate } \\
\text { programs, and they are committed to graduate education through the } \\
\text { doctorate. During the period studied, they awarded at least ten } \\
\text { doctoral degrees per year across three or more disciplines, or at least } \\
20 \text { doctoral degrees per year overall." }\end{array}$ & 3 \\
\hline $\begin{array}{l}\text { Baccalaureate Colleges - General: } \\
\text { - "These institutions are primarily undergraduate colleges with major } \\
\text { emphasis on baccalaureate programs. During the period studied, they } \\
\text { awarded less than half of their baccalaureate degrees in liberal arts } \\
\text { fields." }\end{array}$ & 3 \\
\hline $\begin{array}{l}\text { Associate's Colleges: } \\
\text { - "These institutions offer associate's degree and certificate programs } \\
\text { but, with few exceptions, award no baccalaureate degrees. This } \\
\text { group includes institutions where, during the period studied, } \\
\text { bachelor's degrees represented less than } 10 \text { percent of all } \\
\text { undergraduate awards." }\end{array}$ & 1 \\
\hline $\begin{array}{l}\text { Doctoral/Research Universities-Extensive: } \\
\text { - "These institutions typically offer a wide range of baccalaureate } \\
\text { programs, and they are committed to graduate education through the } \\
\text { doctorate. During the period studied, they awarded } 50 \text { or more } \\
\text { doctoral degrees per year across at least } 15 \text { disciplines." }\end{array}$ & 3 \\
\hline $\begin{array}{l}\text { Specialized Institutions - Other separate health profession schools: } \\
\text { - "These institutions award most of their degrees in such fields as } \\
\text { chiropractic, nursing, pharmacy, or podiatry." }\end{array}$ & 1 \\
\hline $\begin{array}{l}\text { Baccalaureate Colleges-Liberal Arts: } \\
\text { - "These institutions are primarily undergraduate colleges with major } \\
\text { emphasis on baccalaureate programs. During the period studied, they } \\
\text { awarded at least half of their baccalaureate degrees in liberal arts } \\
\text { fields." }\end{array}$ & 1 \\
\hline
\end{tabular}




\title{
APPENDIX B
}

\section{Text/Sequence of Emails}

\author{
Email \#1: General Inquiry
}

Hello. I am a library science student at UNC-Chapel Hill and I am trying to get into contact with the person at your library who manages/chooses titles for your library's McNaughton Collection (leased popular fiction collection). If you could email me his/her name and email/contact info I would really appreciate it. I am hoping to contact them for assistance with my master's paper.

Thanks so much!

Email \#2: Inquiry of Participation to Staff Member

Dear (name of staff member),

I was given your name in response to an email I had written to the "Ask a Question" service on your library's homepage in regards to the person in charge of managing/choosing titles for the McNaughton Collection in your library. I am a library science student at UNC-Chapel Hill at work on my master's paper which is focusing on the use of leased popular literature collections in academic libraries. I am wondering if you would be willing to help with my research by answering a brief survey (it should only take about 10 minutes to complete) about the leased collection at your library (number of titles; who chooses the titles; who uses the collection, etc). I am hoping to mail out the surveys early next week to those who are willing to participate. If this is something you wouldn't mind helping with, can you reply to this email with your address? Again, thanks for taking the time to write me back!

\section{Email \#3: Follow-up Reminder}

Hi (name of staff member),

I just wanted to make contact with you to confirm that you have received the survey I mailed out a few weeks ago. I am hoping to begin compiling results as early as next week and every response counts. If there are any questions or concerns you might have that may be holding up its completion and return, please let me know.

Thanks again for your time and participation! 


\section{APPENDIX C}

\section{Survey Questions}

\section{Making Sense of Leased Popular Literature Collections}

Directions for completing this survey:

- Please answer questions as thoughtfully and honestly as possible.

- Some questions require choosing from options provided. For these questions, please feel free to write any additional comments you may have to clarify the practices of your library.

- Please do not write your name anywhere on this survey.

1. How many years has your library used the McNaughton Book Service to lease a popular literature collection?

2. Did your library consider any other lending companies besides McNaughton?
a. No
b. Yes

$\llbracket$ Please list the other companies considered.

3. Does your library lease popular literature titles instead of collecting popular literature for the library's permanent collection?
a. Yes
b. No

4. Does your library lease popular literature titles in addition to collecting popular literature for the library's permanent collection?
a. Yes
b. No 
5. In your opinion, do you think your library should be doing more to collect popular literature titles (especially those considered to fall under the genres: romance, mystery, western, science fiction) for the permanent collection?
a. Yes
b. No

$\mathbb{\square}$ Why/Why not?

6. Does the university that your library supports have popular culture courses that would benefit from having popular literature as part of the permanent collection?
a. Yes
b. No

7. From the list below, please circle the categories of books included in your library's leased popular literature collection:

a. Genre Fiction:
i. Romance
ii. Mysteries
iii. Westerns
iv. Science-Fiction

b. Best-selling General Fiction

c. Nonfiction

d. Biographies

$\mathbb{} \longrightarrow$ Please list here any other categories included in the collection not
mentioned in the list above:

8. How many titles, on average, make up the leased literature collection? 
9. Realizing that circulation statistics are difficult to ask for, would you state that the titles in the leased collection in your library circulate:

a. More than what was expected when the collection was added to your library.

b. Less than what was expected when the collection was added to your library.

c. About what was expected when the collection was added to your library.

10. What is the professional title of the staff member in charge of choosing the titles to be added to the leased collection?

11. Please select all that apply from the following options to describe the staff member who is in charge of selecting titles for the leased popular literature collection:

a. Has personal interest in popular literature.

b. When reading for pleasure, this staff member reads genre fiction (westerns/mysteries/romance/science fiction).

c. Has collection development training/experience.

d. Was chosen at random to be in charge of selecting titles for the collection without having any personal interest in popular literature.

12. Does this person have an M.L.S.?
a. Yes
b. No

13. On average, what percent of the titles does your library purchase each year after the leasing period is over?

14. What are the criteria used to select titles from the leased collection for purchasing and adding to the permanent collection? (Example: circulation statistics; name recognition; etc.) 
15. Where in your library is the collection located (Example: the undergraduate library basement; the graduate library reading room; etc.)?

16. Is there proper signage leading users to the collection without their having to ask a staff member for directions?
a. Yes
b. No

17. Is the collection mentioned on your library's website?
a. Yes
b. No

18. Is there a reading room near the collection that provides for comfortable and relaxed reading?
a. Yes
b. No

19. Out of the options below, who would you say uses the collection the most:
a. Staff/faculty
b. Undergraduate Students
c. Graduate Students
d. Community Members

20. Out of the options below, what would you say is the main reason the collection is used for:
a. Pleasure reading.
b. Research for a popular culture studies course.
c. A balanced mix of both pleasure reading and research. 
21. In your opinion, what service does the leased popular literature collection provide for your users that your library's general collection does not?

22. In your opinion as a library staff member, what are the values/benefits of having a leased popular literature collection in your library?

23. If there are any comments you would like to add, or items you think were missed on this survey, please write them here. 


\section{APPENDIX D:}

Tables of Survey Results:

- 22 out of 25 libraries answered survey for an overall return rate of $88 \%$.

Question 1: How many years has your library used the McNaughton Book Service to lease a popular literature collection?

Results: Answers range from 1.5 to 35 years (with an average of 12.3 years)

Question 2: Did your library consider any other lending companies besides McNaughton?

\begin{tabular}{|c|c|c|c|}
\hline $\begin{array}{c}\text { Results: } \\
\text { (out of 22) }\end{array}$ & $\begin{array}{c}\text { Yes: } 2 \\
\text { (Baker \& Taylor) }\end{array}$ & No: 18 & Don't know: 2 \\
\hline
\end{tabular}

Question 3: Does your library lease popular literature titles instead of collecting popular literature for the library's permanent collection?

\begin{tabular}{|c|c|c|}
\hline $\begin{array}{c}\text { Results: } \\
\text { (out of 22) }\end{array}$ & $\begin{array}{c}\text { Yes: } 14 \\
(64 \%)\end{array}$ & $\begin{array}{l}\text { No: } 8 \\
(36 \%)\end{array}$ \\
\hline
\end{tabular}

Question 4: Does your library lease popular literature titles in addition to collecting popular literature for the library's permanent collection?

\begin{tabular}{|c|c|c|}
\hline $\begin{array}{c}\text { Results: } \\
\text { (out of 22) }\end{array}$ & $\begin{array}{c}\text { Yes: } 11 \\
(50 \%)\end{array}$ & $\begin{array}{c}\text { No: } 11 \\
(50 \%)\end{array}$ \\
\hline
\end{tabular}




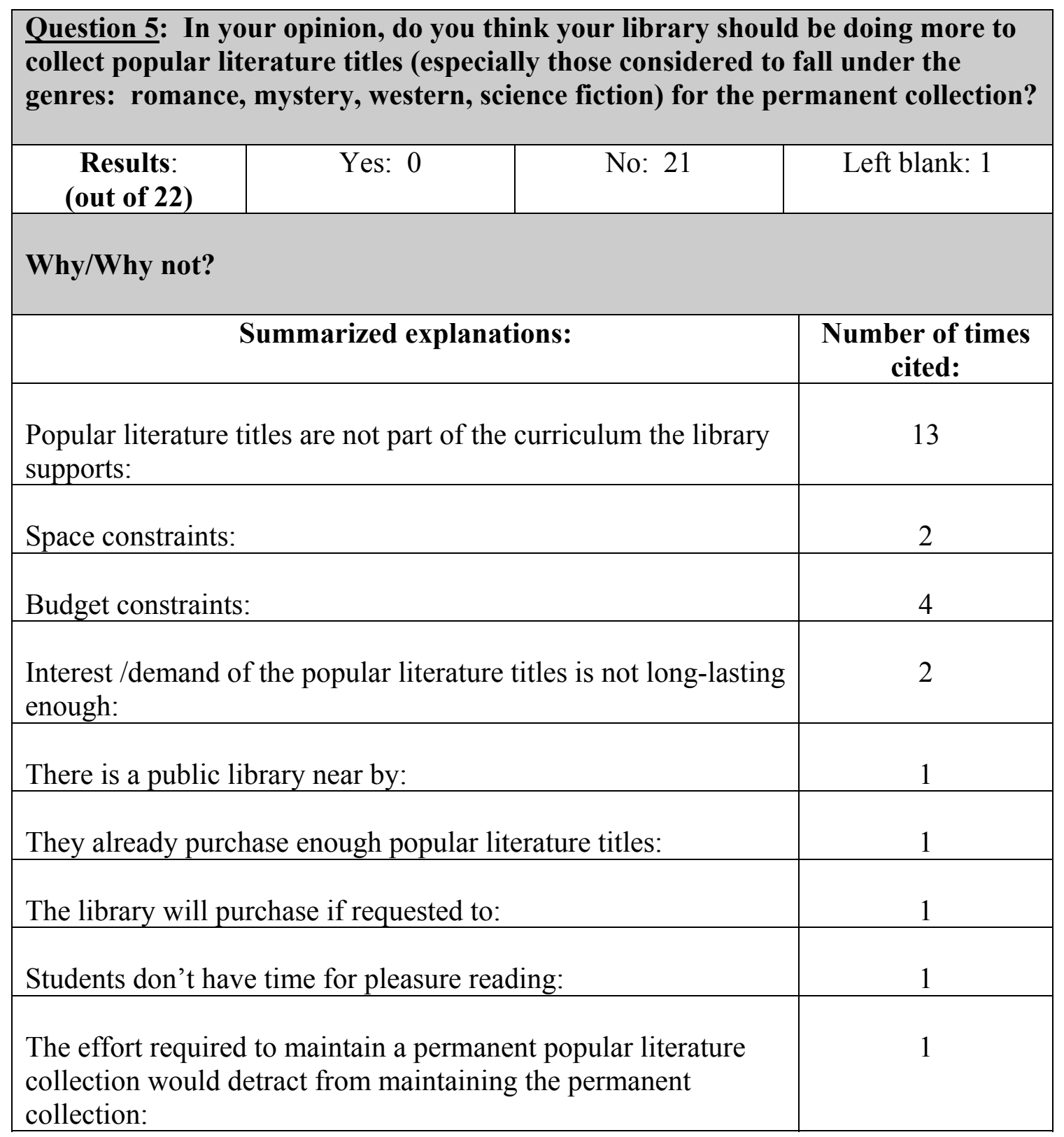

\begin{tabular}{|c|c|c|c|}
\hline \multicolumn{4}{|c|}{$\begin{array}{l}\text { Question 6: Does the university that your library supports have popular culture } \\
\text { courses that would benefit from having popular literature as part of the } \\
\text { permanent collection? }\end{array}$} \\
\hline $\begin{array}{c}\text { Results: } \\
\text { (out of 22) }\end{array}$ & $\begin{array}{l}\text { Yes: } 9 \\
(41 \%)\end{array}$ & $\begin{array}{l}\text { No: } 12 \\
(55 \%)\end{array}$ & $\begin{array}{c}\text { Maybe: } 1 \\
(4 \%)\end{array}$ \\
\hline
\end{tabular}




\begin{tabular}{|c|c|c|c|}
\hline \multicolumn{4}{|c|}{$\begin{array}{l}\text { Question 7: From the list below, please circle the categories of books included in } \\
\text { your library's leased popular literature collection: }\end{array}$} \\
\hline $\begin{array}{l}\text { Categories of } \\
\text { books: }\end{array}$ & $\begin{array}{c}\text { Number of times } \\
\text { selected by } \\
\text { respondents: }\end{array}$ & $\begin{array}{l}\text { Categories of } \\
\text { books: }\end{array}$ & $\begin{array}{c}\text { Number of times } \\
\text { selected by } \\
\text { respondents: }\end{array}$ \\
\hline Romance: & $18(82 \%)$ & Mysteries: & $22(100 \%)$ \\
\hline Westerns: & $15(68 \%)$ & Science-Fiction: & $21(95 \%)$ \\
\hline $\begin{array}{l}\text { Best-Selling } \\
\text { General Fiction: }\end{array}$ & $22(100 \%)$ & Nonfiction: & $21(95 \%)$ \\
\hline Biographies: & $22(100 \%)$ & & \\
\hline \multicolumn{4}{|c|}{ Other categories of books written in by respondents: } \\
\hline $\begin{array}{l}\text { Business } \\
\text { Nonfiction: }\end{array}$ & 2 & Self-Help: & 1 \\
\hline How-to books: & 1 & Spirituality: & 1 \\
\hline Cookbooks: & 1 & Travel: & 1 \\
\hline College Life: & 1 & Food: & 1 \\
\hline
\end{tabular}

\begin{tabular}{|c|c|c|c|}
\hline \multicolumn{4}{|c|}{$\begin{array}{l}\text { Question 8: How many titles, on average, make up the leased literature } \\
\text { collection? }\end{array}$} \\
\hline $\begin{array}{c}\text { Range of } \\
\text { number of titles: }\end{array}$ & $\begin{array}{l}\text { Number of times } \\
\text { cited in that range } \\
\text { (out of 22): }\end{array}$ & $\begin{array}{l}\text { Range of number } \\
\text { of titles: }\end{array}$ & $\begin{array}{l}\text { Number of times } \\
\text { cited in that range } \\
\text { (out of 22): }\end{array}$ \\
\hline 0-199: & 1 & 600-799: & 2 \\
\hline 200-399: & 8 & 800-999: & 2 \\
\hline 400-599: & 8 & $1000+:$ & 1 \\
\hline
\end{tabular}

Question 9: Realizing that circulation statistics are difficult to ask for, would you state that the titles in the leased collection in your library circulate:

a) More than what was expected when the collection was added to your library.

b) Less than what was expected when the collection was added to your library.

c) About what was expected when the collection was added to your library.

\begin{tabular}{|c|c|c|c|c|}
\hline $\begin{array}{c}\text { Results: } \\
\text { (out of 22) }\end{array}$ & $\begin{array}{c}\text { A: } 5 \\
(23 \%)\end{array}$ & $\begin{array}{c}\text { B: } 3 \\
(14 \%)\end{array}$ & $\begin{array}{c}\text { C: } 12 \\
(54 \%)\end{array}$ & $\begin{array}{c}\text { Don't know: } 2 \\
(9 \%)\end{array}$ \\
\hline
\end{tabular}


Question 10: What is the professional title of the staff member in charge of choosing the titles to be added to the leased collection?

Results: The responses varied greatly (from music librarian to library director to all library staff - including students) and as such, a most common professional title or responsible department could not be concluded.

Question 11: Please select all that apply from the following options to describe the staff member who is in charge of selecting titles for the leased popular literature collection:

e. Has personal interest in popular literature.

f. When reading for pleasure, this staff member reads genre fiction (westerns/mysteries/romance/science fiction).

g. Has collection development training/experience.

h. Was chosen at random to be in charge of selecting titles for the collection without having any personal interest in popular literature.

\begin{tabular}{c|c|c|c|c} 
Results: & A: 18 & B: 11 & C: 16 & D: 4 \\
& $(82 \%)$ & $(50 \%)$ & $(73 \%)$ & $(18 \%)$
\end{tabular}

\begin{tabular}{|c|c|c|c|}
\hline Question 12: Does this person have an M.L.S.? \\
\hline $\begin{array}{c}\text { Results } \\
\text { (out of 22): }\end{array}$ & Yes: 16(73\%) & No: 4 (18\%) & $\begin{array}{c}\text { Yes \& No: } 2(9 \%) \\
\text { (i.e.,more than one } \\
\text { person responsible) }\end{array}$ \\
\hline
\end{tabular}

Question 13: On average, what percent of the titles does your library purchase each year after the leasing period is over?

\begin{tabular}{|l|c|l|c|}
\hline $\begin{array}{c}\text { Range of } \\
\text { percent: }\end{array}$ & $\begin{array}{c}\text { Number reported } \\
\text { in that range out of } \\
\mathbf{2 2 :}\end{array}$ & Range of percent: & $\begin{array}{c}\text { Number reported } \\
\text { in that range out of } \\
\mathbf{2 2 :}\end{array}$ \\
\hline $0 \%:$ & 8 & $21-30 \%:$ & 4 \\
\hline $1-10 \%:$ & 6 & $31-40 \%:$ & 2 \\
\hline $11-20 \%:$ & 1 & $41 \%+:$ & 1 \\
\hline
\end{tabular}




\begin{tabular}{|c|c|}
\hline \multicolumn{2}{|c|}{$\begin{array}{l}\text { Question 14: What are the criteria used to select titles from the leased collection } \\
\text { for purchasing and adding to the permanent collection? (Example: circulation } \\
\text { statistics; name recognition; etc.) }\end{array}$} \\
\hline Criteria reported: & Number of times cited in survey: \\
\hline Name recognition/well-known author: & 11 \\
\hline Circulation statistics: & 8 \\
\hline If it supports curriculum: & 8 \\
\hline $\begin{array}{l}\text { If requested for purchase by faculty/staff } \\
\text { member: }\end{array}$ & 4 \\
\hline If a title is well-reviewed: & 4 \\
\hline We don't purchase at all: & 4 \\
\hline If a title has enduring value: & 1 \\
\hline $\begin{array}{l}\text { Titles are chosen at random (has interesting } \\
\text { title, etc.): }\end{array}$ & 1 \\
\hline If it's in good physical condition: & 1 \\
\hline If a title is of regional interest: & 1 \\
\hline
\end{tabular}

\begin{tabular}{|c|c|}
\hline \multicolumn{2}{|c|}{$\begin{array}{l}\text { Question 15: Where in your library is the collection located (Example: the } \\
\text { undergraduate library basement; the graduate library reading room; etc.)? }\end{array}$} \\
\hline Physical location reported: & Number of times cited: \\
\hline Main floor of library: & 8 \\
\hline In a reading room: & 5 \\
\hline Near the periodicals: & 4 \\
\hline Near the main entrance to the library: & 4 \\
\hline Near the reference desk: & 3 \\
\hline Near the circulation desk: & 2 \\
\hline Other: & 5 \\
\hline Left blank: & 1 \\
\hline
\end{tabular}




\begin{tabular}{|c|c|c|c|}
\hline \multicolumn{4}{|c|}{$\begin{array}{l}\text { Question 16: Is there proper signage leading users to the collection without their } \\
\text { having to ask a staff member for directions? }\end{array}$} \\
\hline $\begin{array}{c}\text { Results } \\
\text { (out of 22): }\end{array}$ & $\begin{array}{l}\text { Yes: } 14 \\
(64 \%)\end{array}$ & $\begin{array}{l}\text { No: } 7 \\
(32 \%)\end{array}$ & $\begin{array}{c}\text { Left blank: } 1 \\
(4 \%)\end{array}$ \\
\hline
\end{tabular}

\begin{tabular}{|c|c|}
\hline \multicolumn{3}{|c|}{ Question 17: Is the collection mentioned on your library's website? } \\
\hline \begin{tabular}{c|c|c|}
\hline Results & Yes: 14 & No: 8 \\
(out of 22): & $(64 \%)$ & $(36 \%)$ \\
\hline
\end{tabular}
\end{tabular}

\begin{tabular}{|c|c|c|}
\hline \multicolumn{3}{|c|}{$\begin{array}{l}\text { Question 18: Is there a reading room near the collection that provides for } \\
\text { comfortable and relaxed reading? }\end{array}$} \\
\hline $\begin{array}{c}\text { Results } \\
\text { (out of 22): }\end{array}$ & $\begin{array}{l}\text { Yes: } 22 \\
(100 \%)\end{array}$ & No: 0 \\
\hline
\end{tabular}

\begin{tabular}{|c|c|}
\hline $\begin{array}{l}\text { Question 19: Out of the options below, wh } \\
\text { most: }\end{array}$ & you say uses the collec \\
\hline Options: & Number of times selected: \\
\hline a. Staff/Faculty: & 13 \\
\hline b. Undergraduate Students: & 3 \\
\hline c. Graduate Students: & 0 \\
\hline d. Community Members: & 0 \\
\hline Other (combinations chosen by respondent): & $a b=4, a c=1, a b c d=1$ \\
\hline
\end{tabular}

\begin{tabular}{|c|c|c|c|}
\hline \multicolumn{4}{|c|}{$\begin{array}{l}\text { Question 20: Out of the options below, what would you say is the main reason } \\
\text { the collection is used for: } \\
\text { a. Pleasure reading. } \\
\text { b. Research for a popular culture studies course. } \\
\text { c. A balanced mix of both pleasure reading and research. }\end{array}$} \\
\hline $\begin{array}{l}\text { Results (out of } \\
\text { 22): }\end{array}$ & $\begin{array}{l}\text { A: } 22 \\
(100 \%)\end{array}$ & B: 0 & C: 0 \\
\hline
\end{tabular}




\begin{tabular}{|l|c|}
\hline \multicolumn{2}{|l|}{$\begin{array}{l}\text { Question 21: In your opinion, what service does the leased popular literature } \\
\text { collection provide for your users that your library's general collection does not? }\end{array}$} \\
\hline \multicolumn{1}{|c|}{ Services reported: } & Number of times cited: \\
\hline Access to current/popular titles: & 9 \\
\hline Recreational reading: & 4 \\
\hline $\begin{array}{l}\text { Expands the range/variety of reading materials } \\
\text { available on campus: }\end{array}$ & 2 \\
\hline $\begin{array}{l}\text { Saves time and money of users (don't have to } \\
\text { purchase new books or go to public library): }\end{array}$ & 2 \\
\hline Provides multiple copies of popular titles: & 2 \\
\hline
\end{tabular}

\begin{tabular}{|l|c|}
\hline \multicolumn{2}{|l|}{$\begin{array}{l}\text { Question 22: In your opinion as a library staff member, what are the values/benefits } \\
\text { of having a leased popular literature collection in your library? }\end{array}$} \\
\hline \multicolumn{1}{|c|}{ Values/benefits reported: } & Number of times cited: \\
\hline Access/convenience to popular literature titles: & 70 \\
\hline Pleasure reading material: & 5 \\
\hline Good public relations tool: & 5 \\
\hline $\begin{array}{l}\text { Cost-effective for library (access without have to } \\
\text { purchase): }\end{array}$ & 4 \\
\hline Adds variety to library collection: & 2 \\
\hline $\begin{array}{l}\text { Library staff members are able to review titles } \\
\text { before purchasing: }\end{array}$ & 2 \\
\hline Promotes discussion and life-long reading: & 2 \\
\hline Multiple copies/quick turnover of recent titles: & 2 \\
\hline Saves space: & \\
\hline Alleviates stress on the local public library: & 1 \\
\hline
\end{tabular}


Question 23: If there are any comments you would like to add, or items you think were missed on this survey, please write them here.

Comments included:

- Cost-effective collection development tool.

- Students don't have time/seem interested in collection.

- If collection was removed, there would be a protest.

- Leased collection is funded by donations to university foundation.

- Used to be affectionately referred to as the "trash collection."

- Collection provides "in-demand" titles and come pre-processed (time saving).

- Good place to promote multi-culturalism by having minority authors and biographies about minorities in collection. 